\title{
The Effect of Work Enjoyment and Work-life Balance on Organizational Citizenship Behavior with Job Satisfaction as Mediator
}

\author{
Noor Erdianza, Fatwa Tentama, Erita Yuliasesti Diah Sari
}

\begin{abstract}
The purpose of this study was to examine the effect of work enjoyment and work-life balance on organizational citizenship behavior (OCB) with job satisfaction as a mediator in property companies. This study designed an organizational citizenship behavior model, hence Model testing consists of the Outer and Inner models with the help of the Smart PLS 3.0 program. Data collection methods in the study used the scale of organizational citizenship behavior, job satisfaction, work enjoyment, and work-life balance. Research subjects were 104 employees at property companies. The analysis showed that the organizational citizenship behavior model that was designed was fit based on a GoF value of 0.78 , then it was found that there was no effect of work enjoyment on organizational citizenship behavior with job satisfaction as a mediator; there is an effect of work-life balance on organizational citizenship behavior with job satisfaction as a mediator; there is an influence of work enjoyment on organizational citizenship behavior; there is an effect of work-life balance on organizational citizenship behavior; there is an influence of job satisfaction on organizational citizenship behavior; there is no effect of work enjoyment on job satisfaction; and there is an effect of work-life balance on job satisfaction.
\end{abstract}

Keywords: Work Enjoyment, Work-life Balance, Job Satisfaction, Organizational Citizenship Behavior, Partial Least Square.

\section{INTRODUCTION}

The company is a business unit that deals in certain business fields. In addition, the company also considered an organized institution that aims to obtain profits. The company has certain functions that support and interrelate with one another to achieve a common goal. The function is managed by a management system that is very important to influence the activities in a company. One of the important management systems managed by a company is the human resource management system [1].

Companies must pay extra attention to their employees given the importance of Human Resources (HR) in an organization. That is because the effectiveness and success

Revised Manuscript Received on March 13, 2020.

* Correspondence Author

Noor Erdianza*, Master of Psychology Profession, Ahmad Dahlan University, Yogyakarta, Indonesia. Email: echaerdianza@gmail.com

Fatwa Tentama*, Master of Psychology, Ahmad Dahlan University, Yogyakarta, Indonesia. Email: fatwa.tentama@psy.uad.ac.id

Erita Yuliasesti Diah Sari, Master of Psychology Preofession, Ahmad Dahlan University, Yogyakarta, Indonesia. Email: ediahsari@gmail.com

(C) The Authors. Published by Blue Eyes Intelligence Engineering and Sciences Publication (BEIESP). This is an open access article under the CC BY-NC-ND license (http://creativecommons.org/licenses/by-nc-nd/4.0/) of an organization are very dependent on the quality and performance of the existing human resources in the organization. High performance of human resources (employees) will encourage the emergence of organizational citizenship behavior (OCB), which is a mutual help or prosocial behavior beyond what has been standardized by the company [2].

Organizational citizenship behavior is individual behavior that indirectly promotes the effective functioning of the organization. Such behavior is not a requirement of the role or job but rather more behavior which is a matter of personal choice [3]. In turn, organizational citizenship behavior is an effort made by members of an organization to advance or promote its organization in achieving its goals, so that if organizational citizenship behavior is low, it can have an impact on organizational performance and also affect organizational success [4].

There are several benefits generated when employees have organizational citizenship behavior for an organization such as increasing the productivity of managers and coworkers, saving resources owned by management and the organization as a whole, a means to coordinate team activities effectively, providing increased ability for organizations to recruit and retain employees with good quality performance, maintain stability of organizational performance, help the organization's ability to maintain and adapt to changes in the environment, increase the ability to adapt to environmental changes and contribute to helping organizations become more effective by making social capital [3].

According to interviews conducted on June 17, 2019, several employees of PT. KZL mentioned that other employees only provide help on matters related to work so that mutual assistance between employees outside of work or between sections is less optimal. In addition, some employees also feel uncomfortable at work due to inadequate facilities such as parking lots, room conditions that are quite dense and a rather slow procurement process. On the other hand, when there are activities or events held by the company some employees did not involve or participate in these activities. Besides, the lack of research related to organizational citizenship behavior in the property industry and the holding company provides the rationale for this study for further study.

Factors that influence organizational citizenship behavior of employees are employee commitment, employee motivation,

Published By:

Blue Eyes Intelligence Engineering \& Sciences Publication

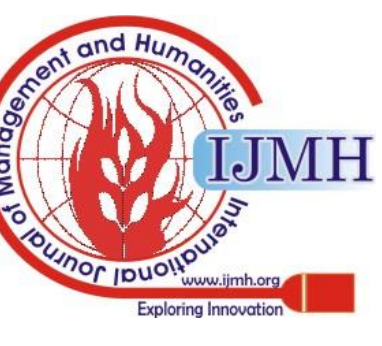


perceived organizational support, job satisfaction, organizational culture, work-life balance, and work enjoyment. This research will discuss the factors of job satisfaction, work enjoyment, and work-life balance. Job satisfaction is a pleasant feeling that is developed by employees all the time about the aspects of their work. This attitude starts from employee perceptions about his work so that satisfaction comes from various aspects of work such as wages, promotion opportunities, and coworkers [5].

Based on research that has been done that the process of improving organizational citizenship behavior depends on employee satisfaction when employees have good job satisfaction it will influence OCB and employee performance. In addition, job satisfaction has an influence and is significant as a mediator of organizational citizenship behavior [6]. This can be seen from employees who have a high level of satisfaction that will encourage OCB, especially when they get support from the company [7].

Organizational citizenship behavior is influenced by two main factors; external factors or factors that are outside the employee such as management systems, corporate culture, and leadership systems; while internal or internal factors such as satisfaction, morals, and positive attitudes [8]. Internal factors in organizations are known as positive attitudes that are related to organizational citizenship behavior, these positive attitudes are one aspect of the dimensions of work enjoyment [9]. Work enjoyment is a feeling of enjoying work that will encourage enthusiasm in working with full responsibility for every employee. Employees who show enthusiasm for work will have a positive involvement in their work [10].

Organizational citizenship behavior can arise from various factors in an organization, such factors are due to work-life balance. Work-life balance is the extent to which individuals can balance between roles in work and outside of work [11]. According to the research conducted by Redwood (2014) in JobStreet.com in the United Kingdom concludes that the organizations that encourage employees to have a balance between work and personal life will earn $20 \%$ more income than organizations that do not [12]. This is also supported by other research that employees who can achieve a balance between work and family will have positive and loyal behaviors in organizations [13].

Based on the previous explanation, many factors are influencing organizational citizenship behavior among employees, so that the researchers conducted a study to find out the influence of job satisfaction, work enjoyment, and work-life balance on organizational citizenship behavior on employees in property companies.

\section{A. Work Enjoyment and OCB}

Work enjoyment is the employee's comfortable feeling at work that gives rise to enthusiasm for work and helps to overcome obstacles in completing their duties. Employees who enjoy their work will see these obstacles as a challenge that makes them think positively [14]. This is in line with previous research that positive emotions can help individual to grow. Positive emotions such as joy, love, admiration, gratitude, hope, and desire to progress are very important to individual's success [15].

Research explains that the intrinsic motivation dimension is the key to work enjoyment so that it has a positive influence on organizational citizenship behavior. Therefore, work enjoyment is defined as the extent to which individuals work because they find work interesting or fun through intrinsic motivation [16]. Besides, the dimension of selfesteem is one of the predictors of the emergence of work enjoyment which also has an impact on career satisfaction, performance and psychological reactions such as anxiety and depression [17].

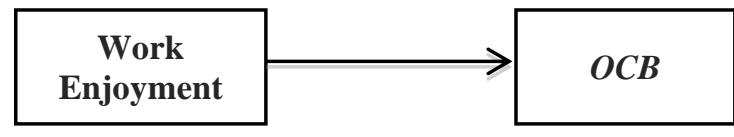

Figure 1. Work enjoyment to OCB

\section{B. Work-life Balance and OCB}

Work-life balance is the extent to which individuals are equally involved in work and family life and are equally satisfied in both [18]. Research shows that work-life balance has a positive effect on organizational citizenship behavior. The study used dimensions of work-life balance that include social needs, personal needs, time management, time work, compensation, and benefits, meanwhile, the organizational citizenship behavior aspects used are altruism, conscientiousness, courtesy, civic virtue, and sportsmanship with a beta value of 0.475 [19]

Employees who are able to balance their work and personal activities will reduce absenteeism, improve performance, and lead to organizational citizenship behavior that affects organizational productivity [19]. This is in line with research that showed a positive relationship between work-life balance and organizational citizenship behavior. Employees who have a balance between work and family will reduce the intensity of turnover and increase organizational citizenship behavior [20].

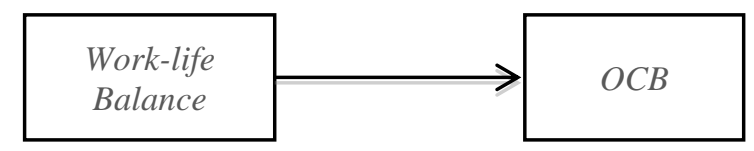

Figure 2. Work-life Balance to

\section{Work Enjoyment and Job Satisfaction}

Research shows that work enjoyment is very relevant and has a positive effect on job satisfaction for doctors who have worked for 5 years compared to doctors who have worked for 1 year. That is because doctors who have worked for 5 years have a lot of experience so that they feel comfortable working compared to doctors who have only worked for 1 year [21]. Work enjoyment has affective components those are pleasure and interest and has a positive effect on job satisfaction in the organization. Work enjoyment can generate certain cognitive patterns, coping, increase work attitude, welfare, learning, ability to adapt, and employee performance that contribute to organizational goals [16].

Research shows that the dimensions of work enjoyment include absorption and intrinsic motivation that have an important role in empowering employees in an organization.

Published By:

Blue Eyes Intelligence Engineering \& Sciences Publication

(C) Copyright: All rights reserved.

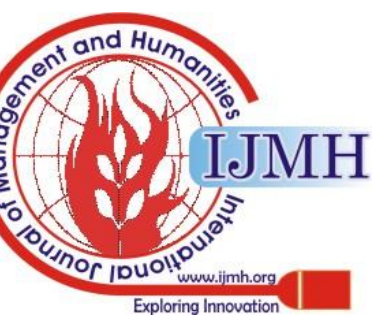

Exploring Innovation 
This is because absorption refers to the state when individuals completely immersed in his work and intrinsic motivation refers to the desire of individuals to carry out an activity so that they experience satisfaction from their work. The result showed a positive relationship between work enjoyment and employee empowerment as seen from the absorption value of $\mathrm{B}=0.43 ; \mathrm{p}<0.001$ and intrinsic motivation $\mathrm{B}=0.40 ; \mathrm{p}<0.001$ [22].

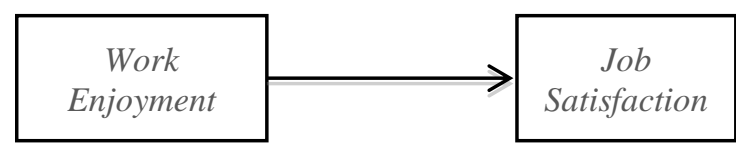

Figure 3. Work Enjoyment to Job Satisfaction

\section{Work-life Balance and Job Satisfaction}

Research that has been done shows that there is a positive and significant relationship between work-life balance with job satisfaction among educational staff in universities with a sample of 98 people. The research refers to aspects of job satisfaction which include the job itself, salary, promotion opportunities, supervision, and coworkers, while work-life balance refers to the dimensions of time management, involvement balance, and satisfaction balance with a value of $\mathrm{r}=0.610 ; \mathrm{p}<0.001$ [23].

Research suggests that employees will achieve work-life balance when they feel satisfied and effective in parts of their lives so that the factors that encourage job satisfaction and effectiveness in work and family will improve balance. Whereas the factors which hamper job satisfaction and effectiveness in work and family will weaken the balance of work and family [24].

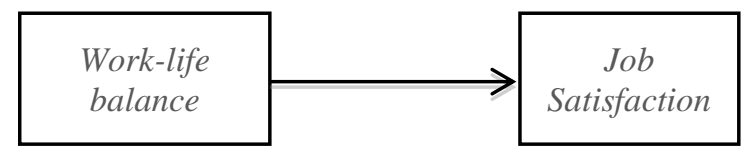

Figure 4. Work-life Balance to Job Satisfaction

\section{E. Job Satisfaction and OCB}

Organ and Bateman suggest that all aspects of job satisfaction that include wages, promotion opportunities, supervision, self-employment, and coworkers positively correlated with aspects of organizational citizenship behavior [25]. This is aligned with research conducted showing that job satisfaction has a positive effect on organizational citizenship behavior. The study refers to aspects of job satisfaction that consist of work itself, wages, promotions, supervision, and coworkers, whereas organizational citizenship behavior refers to aspects of altruism, conscientiousness, courtesy, civic virtue, and sportsmanship with a beta value of 0.561 [26]

Organizational citizenship behavior can arise from several factors, one of which is the existence of job satisfaction from employees [27]. Satisfied employees will have a willingness to do more than their responsibilities. This willingness came to be known as organizational citizenship behavior (OCB), which is behaviors carried out by members of the organization or employees who were not explicitly rewarded when they did it and also were not penalized if they did not. OCB is not part of the job description of the employee [3].

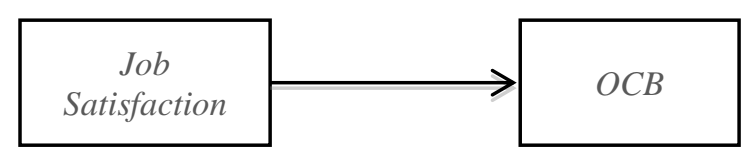

Figure 5. Job Satisfaction to OCB

Based on the explanation above, the relationship between all variables to be examined in this study can be figured as follow:

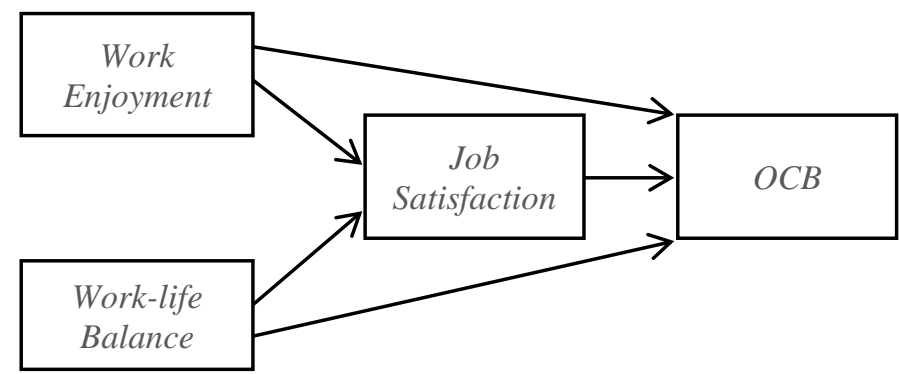

Figure 6. Work enjoyment and Work-life balance to OCB with Job satisfaction as Mediator

\section{METHOD}

\section{A. Population and Sample}

The population in this study starting from the permit to the company and the scale distribution on September 1, 2019, to September 18, 2019, to 120 employees in all departments of the property company. The scale collected after the deployment process is 104 scale. Procedure for filling the scale using the google form application. The scale is spread through the WhatsApp application.

\section{B. Data Collection Method}

This study uses four variables as the background of the problem. These variables are translated into measurement tools in the data collection process. The measuring instrument is the scale that divided into four subscales; OCB scale to measure employee OCB; job satisfaction scale to measure employee job satisfaction; work enjoyment scale to measure employee work comfort; and work-life balance scale to measure the balance of personal and work life of employees. The scale is arranged based on the summated rating model which is made into four alternative response formats.

The summated rating scale used in this study is the Likert scale model. Likert scale is often called the Summated scale (the added scale) which means the ordinal scale [33]. Respondents were asked to answer psychological objects such as job satisfaction. The Likert scale was created using four alternative answers. Code (1) strongly disagrees, (2) disagree, (3) agree, and (4) strongly agree [33].

Published By:

Blue Eyes Intelligence Engineering \& Sciences Publication

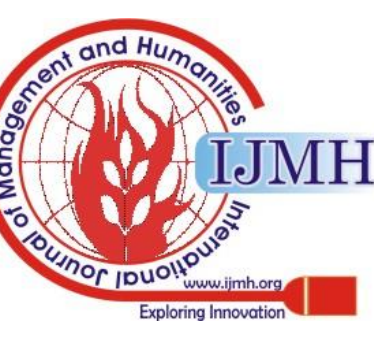


The Effect of Work Enjoyment and Work-life Balance on Organizational Citizenship Behavior with Job Satisfaction as Mediator

\section{Data Analysis}

Data analysis technique used in this study is to use the Structural Equation Modeling (SEM) method. SEM is a combination of two separate statistical methods, namely factor analysis developed in psychology and psychometrics and simultaneous equation modeling developed in ecometrics [33]. The software (software) used to assist in analyzing data is to use computer software programs, one of which is PLS (Partial Least Squares).

The process of evaluating this research model in PLS is done through two stages, namely the evaluation of the measurement model (outer model) and then the evaluation of the structural model (inner model). Fulfillment of the standard provisions in the assessment of the outer model and inner model, then it is stated that the measurement model is fit, and can be continued to carry out a path analysis with the help of bootstrapping.

\section{Validity and Reliability}

The validity and reliability of this study use the outer model in partial least square (PLS). There are two validity tests in construct validity; convergent and discriminant validity. Convergent measures the magnitude of the correlation between item scores and constructs scores, which are assessed based on a loading factor $>0.5$ and average variance extracted (AVE) value $>0.5$ [34]. Discriminant validity is done because different construct gauges should not high correlate where it is expected that the amount of cross-loading between constructs and items is greater than that of other construct values. The rule is the compared AVE roots of a construct must be higher than the correlation between latent variables [35].

The reliability test is completed by looking at the value of composite reliability and Cronbach's [34]. The expected composite reliability and Cronbach's alpha value is $>0.7$, yet the value 0.6 still acceptable, then according to Cooper, the internal consistency test approved if the validity of the extract has met the criteria so that the average variance extracted (AVE) value has represented internal consistency, the valid construct is reliable, but the reliable construct does not necessarily valid [35].

The structural model is a model that connects latent variables. The process of evaluating structural models can use the criteria $R^{2}, f^{2}, Q^{2}$ and $q^{2}$, and also Goodness of Fit (GoF) index [36].

\section{RESULT}

\section{A. Outer Model}

1. Construct Validity

In this study, how to test validity by assessing convergent validity and discriminant validity based on PLS. Convergent validity test results using Average Variance Extracted (AVE) and the minimum requirement indicator AVE value is 0.5 . The, discriminant validity test results using Fornell-Larcker Creation and the minimum requirement indicator is 0.7 . The results of convergent validity and discriminant validity testing can be seen in the table 1 and table 2.
TABLE 1. Convergent Validity

\begin{tabular}{ccc}
\hline Variable & $\begin{array}{c}\text { Average Variance } \\
\text { Extracted (AVE) }\end{array}$ & Explanation \\
\hline Work Enjoyment & 0.520 & Valid \\
\hline Work-life Balance & 0,507 & Valid \\
\hline Job Satisfaction & 0,514 & Valid \\
\hline OCB & 0,522 & Valid \\
\hline
\end{tabular}

Source: Research Result, 2019 (processed data)

TABLE 2. Discriminant Validity

\begin{tabular}{ccc}
\hline Variable & Fornel-Larcker Creation & Explanation \\
\hline Work Enjoyment & 0,721 & Valid \\
\hline Work-life Balance & 0,712 & Valid \\
\hline Job Satisfaction & 0,713 & Valid \\
\hline OCB & 0,723 & Valid \\
\hline
\end{tabular}

Source: Research Result, 2019 (processed data)

\section{Construct Realibility}

Construct reliability in this study using Cronbach's Alpha. This value reflects the reliability of all indicators in the model. The minimum value is 0.7 while the ideal is 0.8 or 0.9. Besides Cronbach's Alpha, the value of $\rho$ c (composite reliability) is used which is interpreted the same as the value of Cronbach's Alpha. The Cronbach's Alpha and composite reliability can be seen in the table 3 .

TABLE 3. Result of Cronbac's Alpha and Composite Reliability

\begin{tabular}{cccc}
\hline Variable & $\begin{array}{c}\text { Cronbach } \\
\text { Alpha }\end{array}$ & $\begin{array}{c}\text { Composite } \\
\text { Reliability }\end{array}$ & Explanation \\
\hline Work Enjoyment & 0.895 & 0.914 & Reliable \\
\hline Work-life Balance & 0,910 & 0,924 & Reliable \\
\hline Job Satisfaction & 0,841 & 0,880 & Reliable \\
\hline OCB & 0,866 & 0,896 & Reliable \\
\hline
\end{tabular}

Source: Research Result, 2019 (processed data)

\section{B. Inner Model}

The result of inner model that has been done using the smart PLS 3.2.8 program can be seen in table 4 .

TABLE 4. Results of Inner Model Analysis

\begin{tabular}{cccc}
\hline \multirow{2}{*}{ Criteria } & \multicolumn{3}{c}{ Value Category } \\
\cline { 2 - 3 } & Strong & Medium & Weak \\
\hline$R^{2}$ & & \\
OCB $(Y)$ & 0,567 & \\
Job Satisfaction $(M)$ & & 0,617 &
\end{tabular}
$Q^{2}$
1,184

\begin{tabular}{cccc}
\hline \multirow{2}{*}{ Criteria } & \multicolumn{3}{c}{ Value Category } \\
\cline { 2 - 3 } & Strong & Medium & Weak \\
\hline$f^{2}$ & & 0,253 &
\end{tabular}

GoF Value 0,780

Source: Research Result, 2019 (processed data)

Based on the categorization results of the four variables, the OCB category is $77 \%$ falls into the high category, the job satisfaction category is 53\% also in the high category, the work enjoyment category is $60 \%$ still in the high category, and the work-life balance category is $65 \%$ falls in the medium category.

Published By:

Blue Eyes Intelligence Engineering \& Sciences Publication 
TABLE 5. Results of Hyphothesis Testing

\begin{tabular}{ccccc}
\hline Model & $\begin{array}{c}\text { St. Dev } \\
\text { (STDEV) }\end{array}$ & $\begin{array}{c}\text { t- } \\
\text { statistic }\end{array}$ & $\begin{array}{c}\text { p- } \\
\text { values }\end{array}$ & Remark \\
\hline JS $\rightarrow$ OCB & 0.104 & 3.103 & 0.002 & Significant \\
$\mathrm{WE} \rightarrow$ JS & 0.109 & 1.945 & 0.052 & Not Significant \\
$\mathrm{WE} \rightarrow$ OCB & 0.093 & 2.817 & 0.005 & Significant \\
$\mathrm{WLB} \rightarrow$ JS & 0.098 & 6.008 & 0.000 & Significant \\
$\mathrm{WLB} \rightarrow$ OCB & 0.102 & 3.096 & 0.002 & Significant \\
\hline
\end{tabular}

Source: Research Result, 2019 (processed data)

The effect of work enjoyment on OCB was found to be significant. This shown in the table (t-statistic $>1.96$ and $\mathrm{p}-$ values $<0.05$ ) with a t-statistic score of $2.817>1.96$ and $\mathrm{p}$ values of $0.005<0.05$ thus it can be concluded that work enjoyment has a direct effect against OCB. This indicates that hypothesis four is accepted.

Based on the results of the hypothesis test the direct relationship between the work-life balance variable to OCB is significant and positively correlated. This can be seen in the table (t-statistic $>1.96$ and $\mathrm{p}$-values $<0.05$ ) with a tstatistic score of 3.096 $>1.96$ and p-values $0.002<0.05$ so that hypothesis five is accepted.

Hypothesis testing shows that the direct relationship between work enjoyment and job satisfaction is not significant. The results of this test suggest that t-statistics $<\mathrm{t}$ table (Sign $5 \%=1.96)$ and p-values $>0.05$. Then it can be concluded that hypothesis six is not proven, that is, work enjoyment does not directly influence job satisfaction.

The effect of work-life balance on job satisfaction is significant. As figured in the table (t-statistic $>1.96$ and pvalues $<0.05$ ) with a t-statistic score of $6.008>1.96$ and $p$ values of $0.000<0.05$. Hence, hypothesis seven is accepted. Based on analysis it is found that the direct relationship between job satisfaction and OCB is significant. This can be seen from the table (t-statistic $>1.96$ and p-values $<0.05)$ tstatistic score 3.103> 1.96 and p-values $0.002<0.05$. Overall, it can be concluded that the eight hypothesis is giving evidance that job satisfaction has a direct effect on OCB.

The bootstrapping stage explains that the variables that have a direct influence on OCB are job satisfaction, work enjoyment, and work-life balance. The following is the model after modification.

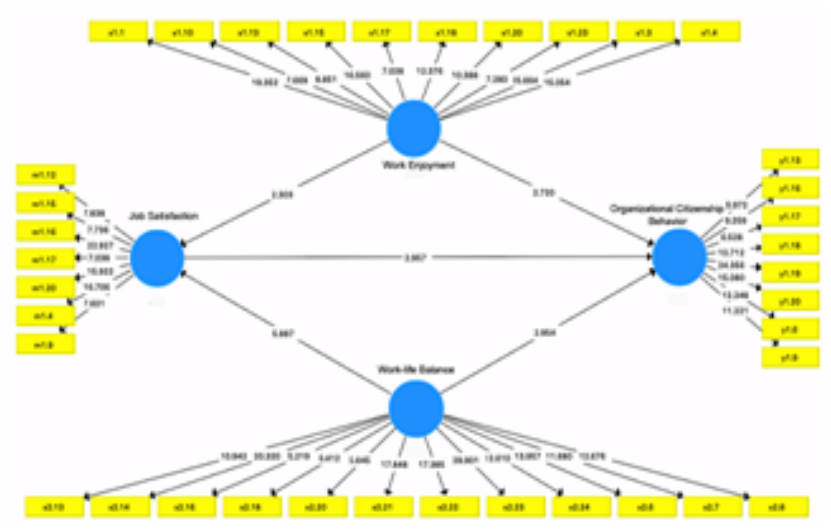

Figure 7. Output Inner Model

\section{B. Mediator}

The result effect of variable mediator in this study can be seen in table 6.

TABLE 6. The Role of Mediator

\begin{tabular}{ccccc}
\hline Model & $\begin{array}{c}\text { St. Dev } \\
\text { (STDEV) }\end{array}$ & $\begin{array}{c}\text { t- } \\
\text { statistic }\end{array}$ & $\begin{array}{c}\text { p- } \\
\text { values }\end{array}$ & Remark \\
\hline $\begin{array}{c}\text { Work Enjoyment } \rightarrow \\
\text { Job Satisfaction } \rightarrow \\
\text { OCB }\end{array}$ & 0.104 & 3.103 & 0.002 & $\begin{array}{c}\text { Not } \\
\text { Significant }\end{array}$ \\
$\begin{array}{c}\text { Work-life balance } \rightarrow \\
\text { Job Satisfaction } \rightarrow \\
\text { OCB }\end{array}$ & 0.109 & 1.945 & 0.052 & Significant \\
\hline
\end{tabular}

Source: Research Result, 2019 (processed data)

The effect of work enjoyment on OCB mediated by job satisfaction was insignificant. This shown in the table (tstatistic $>1.96$ and p-values $<0.05$ ) with a t-statistic score of $1.322<1.96$ and p-values of $0.187>0.05$. The result indicates that job satisfaction does not have a role as a mediator between work enjoyment and OCB, accordingly, it can be concluded that the second hypothesis is not accepted.

The effect of work-life balance on OCB that mediated by job satisfaction was significant. This finding figured in the table (t-statistic $>1.96$ and p-values $<0.05$ ) with a t-statistic score $2.742>1.96$ and p-values $0.006<0.05$. This indicates that job satisfaction has a role as a mediator between worklife balance and OCB so that it can be concluded that the third hypothesis is accepted.

\section{DISCUSSION}

The mediating role of job satisfaction on the effect of work enjoyment and organizational citizenship behavior produces an insignificant category in this study. This explains that the second hypothesis was rejected because there is no influence on the mediating role that occurs. This shows that the effect of work enjoyment on organizational citizenship behavior can be formed even without the presence of other variables such as job satisfaction. To be able to increase voluntary behavior to help employees, companies need to create comfortable working conditions that may include the pleasure associated with work activities, increasing competence in performing the work and responsibilities thus employees can improve their performance and feel satisfied at work [37].

The significant mediating role of job satisfaction indicates that the effect of work-life balance on organizational citizenship behavior can be explained through employee satisfaction with their work. This may happen because employees have been able to divide the role in terms of time and satisfaction at work and also to his personal life that brings internalization of voluntary behavior. Thus, the third hypothesis in this study was accepted. The ability of employees to allocate time and feeling involved in work and personal life encourages employees to bring a positive balance in the workplace and personal life that eventually supports the emergence of work satisfaction,

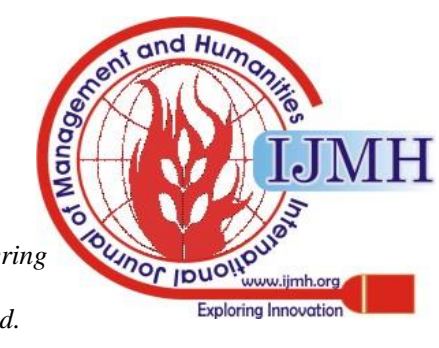


positive contribution behavior to colleagues and organizations.

Work enjoyment does not affect the job satisfaction of employees. Thus, the sixth hypothesis is rejected. Employees who feel comfortable with their work in terms of positive feelings that arise tend do not need promotion. That is because employees will try to complete their work even though they are not given any promotions [38]. This is in line with research that has been done that feeling comfortable at work is subjective for every employee due to the different perceptions about comfort and activities-related to comfort itself [39].

Work-life balance has a positive and significant effect on job satisfaction, so the seventh hypothesis is accepted. This shows that employees who have the ability to manage their work and personal lives can increase the level of satisfaction both in terms of work and personal life aspects. Further, employees who feel balance attachment and satisfaction to their role in the family and workplace may make them more satisfied with their work. Thus, the greater work-life balance employees have, the higher the satisfaction level will be, this satisfaction ranging in terms of salary, promotion and work itself, and vice versa the less work-life balance, the lower satisfaction level [40].

This study proves that there is a significant positive relationship between job satisfaction and organizational citizenship behavior so that the eighth hypothesis is accepted. Companies that work to increase employees' job satisfaction also improve employees' voluntary behavior. Factors that encourage the occurrence of voluntary behaviors such as the right boss, a challenging job, colleagues who respect each other, attractive compensation, and career development [41]. On the other hand, research that has been done on 140 executive employees' level in manufacturing companies in Sri Lanka suggests that there is a positive and voluntary behavior with $r=0.890$, sig $=0,000$ and an effective contribution of 79.1 percent [42].

This research has proven that work enjoyment has a significant and positive effect on organizational citizenship behavior so that the hypothesis is accepted. The result of this study indicates that when employees experience comfort while working, they will tend to do voluntary behavior. Comfort in working can be created when the atmosphere at work supports the creation of a sense of comfort. A conducive and comfortable work environment will make employees feel calm and enjoy while working so that they will be more focused on completing their tasks and responsibilities [39]. This is supported by the previous research that if employees have a sense of comfort in the workplace then they will tend to work exceed their responsibilities [43].

Work-life balance has been proven to have a positive and significant effect on organizational citizenship behavior. Accordingly, the fifth hypothesis is accepted. The result is aligned with the previous research that work-life balance influences voluntary attitudes and behaviors so that it impacts organizational effectiveness. That is may happen because when employees can manage their time, role, and involvement at work tend to be able to maintain good relationships with coworkers and being responsible for organizational activities. Organizations that strategically manage employee time balance, involvement, and satisfaction will bring positive work experience and improve organizational performance [20].

\section{CONCLUSSION}

The result of this study proves that job satisfaction can act as a mediator on the effect of work-life balance on organizational citizenship behavior. On the other hand, job satisfaction does not have a role as a mediator on the effect of work enjoyment on organizational citizenship behavior. Therefore, companies need to consider the three factors in this study that can influence the increase in organizational citizenship behavior of employees, specifically in preparing company policies.

\section{ACKNOWLEDGMENT}

The author would like to thank Ahmad Dahlan University and the Master of Psychology Professional Programme University of Ahmad Dahlan for supporting the implementation of this research.

\section{REFERENCES}

1. Desler, Manajemen sumber daya manusia. Jakarta: Gramedia, 2005.

2. R. Krietner, \& A. Kinicki, Perilaku Organisasi. Jakarta: Salemba 4, 2005.

3. D.W. Organ, P.M. Podsakoff, \& S.B. Mackenzie, Its nature, antecendents, and consequences. New Delhi: Sage Publication, Inc, 2006.

4. R.E. Riggio, Introduction to industrial / organizational Psychology (5 ${ }^{\text {th }}$ Edition). New Jersey: Pearson Education, 2009.

5. S.P. Robbins, Perilaku Organisasi. PT Indeks: Kelompok Gramedia, 2006.

6. S. Swaminathan \& P.D. Jawahar, "Job satisfaction as a predictor of organizational citizenship behavior: An empirical study", Global Journal of Bussiness Research, vol. 7, no. 1, pp. 71-80, 2013.

7. A.P. Prasetio, "Pengaruh work-life balance terhadap organizational citizenship behavior dengan variabel mediasi kepuasan kerja dan komitmen organisasi pada karyawan Bank Rakyat Indonesia kantor Wilayah Bandung”, Prociding MEBC ResearchGate, pp. 1-22, 2017. https://www.researchgate.net/publication/314596433.

8. M.A. Siders., G. George., \& R. Dharwadkar, "The relationship of internal and external commitment foci to objective performance measures", Academy of Management Journal, vol. 44, no. 3, pp. 570579, 2001.

9. A.B. Bakker, "The work-related flow inventory: Construction and initial validation of the WOLF", Journal of Vocational, vol. 72, pp. 400-414, 2007.

10. W.B. Schaufeli, M.P. Leiter \& C. Maslach, "Burnout 35 years of research and practice", Journal of Career Development International, vol. 14, no. 3, pp. 204-220, 2009.

11. J.H. Greenhaus, K.H. Collins \& J.D. Shaw, "The relation beetwen work-family balance and quality of life", Journal of Vocational Behavior, vol. 64, pp. 510-531, 2003.

12. R. Rene \& S. Wahyuni, "Pengaruh work-life balance terhadap komitmen organisasi, kepuasan kerja, dan motivasi kerja terhadap kinerja individu pada karyawan perusahaan asuransi di Jakarta", Jurnal Manajemen dan Bisnis Sriwijaya, vol. 16, no. 1, pp. 53-63, 2018.

13. F. Moore, "Work-life balance: Constrating managers and workers in an MNC", Employee Relations, vol. 29, no. 4, pp. 365-399, 2007.

14. C. Atkinson, \& H. Laura, Flexible working and happiness in The NHS. Inggris: University of Bradford School of Management, 2014.

15. B.L. Frederickson, \& T. Joiner, "Positive emotions trigger upward spirals toward emotional well-being", Psychological Science, vol. 13, no. 2, pp. 172-175, 2002.

Published By:

Blue Eyes Intelligence Engineering \& Sciences Publication 
16. L.M. Graves, M.N. Rudermann, J.P. Ohlot, \& T.J. Weber, "Driven to work and enjoyment of work: Effects on managers' outcome", Journal of Management, vol. 38, no. 5, pp. 1655-1680, 2012.

17. R.F. Baumeister, J.D. Campbell, J.I. Krueger, \& K.D. Vohs, "Does high self-esteem cause better performance, interpersonal success, happiness or healthier lifestyle", Psychological Science in the Public Interest, vol. 4, pp. 1-44, 2003.

18. S.C. Clark, "Work-family border theory, A new theory of work-family balance", Human Relations, vol. 53, no. 6, pp. 747-770, 2000.

19. R.K. Pradhan, L.K. Jena, \& I.G. Kumari, "Effect of work-life balance on organizational citizenship behavior role of organizational commitment”, Global Business Review, vol. 17, no.3S, pp. 3-15, 2016.

20. D.S. Carlson, J.G. Grzywacz, \& K.M. Kacmar, "Work-family balance and supervisor appraised citizenship behavior: The link of positive affect", Institute of Behavior and Applied Management, vol. 14, no. 2 , pp. 87-106, 2013.

21. G. Surman, T.W. Lambert, \& M. Goldacre, "Doctors' enjoyment of their work and satisfaction with time available for leisure: UK time trend questionnaire-based study", Postgrad Med Journal, vol. 92, pp. 194-200, 2016.

22. P. Peters, E. Poutsma, B.I.J.M.V.D. Heijden, A.B. Bakker, \& T.D Brujin, "Enjoying new ways to work: An HRM-process approach to study flow", Human Resource Management, vol. 53, no. 2, pp. 271 290, 2014.

23. C.F. Tarigan \& I.Z. Ratnaningsih, "Hubungan antara work-life balance dengan kepuasan kerja pada tenaga kependidikan di Universitas X", Jurnal Empati, vol. 7, no. 3, pp. 244-251, 2018.

24. J.H. Greenhaus, J.C. Ziegert \& T.D. Allen, "When family-supportive supervision matters: Relation between multiple sources of support and work-family balance", Journal of Vocational Behavior, vol. 80, pp. 266-275, 2012.

25. P. Tritisari, Peranan Organizational Citizenship Bahvior (OCB) dalam Meningkatkan Kinerja Karyawan. Jakarta: Mitra Wacana Media, 2014.

26. P.G.H.A. Charmiati \& I.B.K. Surya, "Pengaruh kepuasan kerja terhadap organizational citizenship behavior dengan komitmen organisasi sebagai variabel mediasi”, E-Journal Management Unud, vol. 8, no. 3, pp. 1784-1812, 2019.

27. S.P. Robbins \& T.A. Judge, Perilaku Organisasi - Organizational Citizenship Behavior. Jakarta: Salemba Empat, 2008.

28. J. Greenberg \& R.A. Baron, Behavior in organizations understanding and managing the human side of work, Third Edition. Massachuscets: Allin and Bacon. A Division of Schuster, 2003.

29. F. Luthans, Organizational behavior: An evidence-based approach New York: McGraw-Hill/Irwin, 2006.

30. R.A. Noe, J.R. Hollenbeck, B. Gerhart, \& P.M. Wright, Fundamentals of Human Resource Management. New York: MacGraw-Hill, 2011.

31. S. Davidson, Multi-dimensional model of enjoyment: Development and validation of an enjoyment scale. Dissertation and Theses, 381, 2018.

32. P. Delecta, "Work-life balance", International Journal of Current Research, vol. 3, no. 4, pp. 186-189, 2011.

33. I. Ghozali, Aplikasi Analisis Multivariate dengan Program IBM SPSS 25. Semarang: Universitas Diponegoro, 2018.

34. J.F. Hair, C.M. Ringle, \& M. Sarstedt, "Editorial partial least squares structural equation modeling: Rigorous Application, better results and higher acceptance", Long Range Planning, vol. 46, no. 1-2, pp. 1-12, 2013.

35. Jogiyanto, Konsep dan aplikasi struktural equation modeling berbasis varian dalam penelitian bisnis. Yogyakarta: STIM YKPN, 2011.

36. E.U.N. Sholiha \& M. Salamah, "Structural equation modeling-partial least square untuk permodelan derajat kesehatan kabupaten / kota di Jawa Timur (Studi Kasus Data Indeks Pembangunan Kesetan Masyarakat Jawa Timur 2013)", Jurnal Sains dan Seni ITS, vol. 4, no. 1, pp. 2337-3520, 2015.

37. M.F. Steger, B.J. Dik \& R.D. Duffy, "Measuring meaningful work: The work and Meaning Inventory (WAMI)", Journal of Career Assesment, vol. 20, no. 3, pp. 322-337, 2012.

38. E. Lamm \& M.D. Meeks, "Workplace fun: The moderating effect of generational differences", Employee Relations Journal, vol. 31, no. 6 , pp. 613-631, 2009.

39. Yanti, "Pengaruh workplace fun terhadap kinerja karyawan berdasarkan generational differences (Studi pada PT BXY)", Jurnal. Jakarta: FISIP UI, 2013

40. E.S. Kassim, S.A. Mat Ali, S.F.A. Jalaini, N.M. Yunus, N.A. Said, D.S. Ab Latiff, F. Shalleh, "Work-life balance and job satisfaction: How relevant are they?", International Conference on Technology, Informatics, Management, Engineering \& Environment. Bandung, June 23-26, (TIME-E), 2013.

Published By:

Blue Eyes Intelligence Engineering \& Sciences Publication the role of the job satisfac

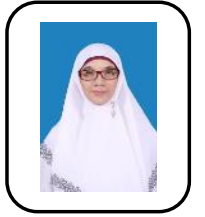
behavior", Coll Antropol, vol. 38, no. 2, pp. 429-436, 2014.

42. V.R. Ranasinghe, "The relationship between job satisfaction and the OCB in fabric manufacturing industry in Sri Lanka", Imperial Journa of Interdisciplinary Research (IJIR), vol. 2, no. 12, pp. 898-904, 2016.

43. T. McDowell, "Fun at work: Scale development. Confirmatory factor analysis and links to organizational outcomes", Disertation, Alliant International University, San Diego. California, 2004.

\section{AUTHORS PROFILE}

Noor Erdianza, was born June 24, 1992 in Makassar. He is a student at Master of Psychology Profession, Universitas Ahmad Dahlan Yogyakarta. His scientific focus is industrial and organization psychology.

Fatwa Tentama, was born on October 1, 1984 in Yogyakarta. Working as a lecturer at the Faculty of Psychology at Ahmad Dahlan University, Yogyakarta. His scientific focus and research is industrial psychology and educational psychology.

Rr. Erita Yuliasesti Diah Sari, was born July 06, 1965 in Banjarnegara. Working as a lecturer at the Faculty of Psychology at Ahmad Dahlan University, Yogyakarta. His scientific focus and research is industrial psychology and educational psychology. 